\title{
STUDIES ON THE ANTI-INFLAMMATORY, ANALGESIC AND ANTIPYREXIC ACTIVITIES OF BETULINIC ACID DERIVED FROM TETRACERA POTATORIA
}

\author{
Bukola Olunike Oyebanji ${ }^{1}$, Adebowale Bernard Saba,", ${ }^{2,}$ Olayinka Ayotunde Oridupa ${ }^{2}$ \\ ${ }^{1}$ Department of Animal Science, Obafemi Awolowo University, Ile-Ife, Nigeria, ${ }^{2}$ Department of Physiology, \\ Biochemistry \& Pharmacology, University of Ibadan, Ibadan, Nigeria \\ *E-mail: bensaba2011@ hotmail.com
}

\begin{abstract}
Background: The anti-inflammatory and anti-nociceptive activity of betulinic acid (BA) was investigated in this study. The triterpene was isolated from the ethyl acetate extract of Tetracera potatoria and its structure was verified by IR and NMR spectroscopy. The bioactivity of this compound was assessed using carrageenan-induced paw oedema in rats and carrageenan-induced pulmonary oedema in mice for the antiinflammatory activity, while acetic acid-induced writhing test in mice and zymosan-induced fever in rats were used for analgesic test.

Materials and Methods: Rats and mice were randomly divided into groups of five animals. For each experiment, betulinic acid at 10,20 or $40 \mathrm{mg} / \mathrm{kg}$ b.w was administered intraperitoneally to the first three groups respectively. The fourth group was administered with indomethacin $(10 \mathrm{mg} / \mathrm{kg})$ or acetylsalicylic acid $(150 \mathrm{mg} / \mathrm{kg})$, while the fifth group was administered with distilled water $(10 \mathrm{ml} / \mathrm{kg})$. Data obtained were expressed as mean \pm S.E.M and significant differences were determined at $\mathrm{p}<0.05$.

Results: BA significantly reduced carrageenan-induced paw oedema by $11.0 \%, 45.7 \%, 68.6 \%$ or pulmonary oedema by $25.6,29.2$ and $45.13 \%$ dose dependently. $40 \mathrm{mg} / \mathrm{kg}$ of BA inhibited paw oedema by $68.6 \%$ comparably to acetylsalicylic acid $(71.4 \%)$ or indomethacin $(51.33 \%)$ respectively. Abdominal writhing was also significantly $(\mathrm{p}<0.05)$ reduced to 17.20 writhes by BA $(40 \mathrm{mg} / \mathrm{kg})$ comparable to Indomethacin (16.3writhes). Fever was inhibited by BA most significantly by 3hours post-injection of zymosan $\left(1.00,1.45,0.00^{\circ} \mathrm{C}\right)$ and this inhibitory effect was higher than that observed for acetylsalicylic acid $\left(0.30^{\circ} \mathrm{C}\right)$.

Conclusion: Betulinic acid derived from Tetracera potatoria exhibited potent anti-inflammatory, analgesic or antipyrexic activity which is comparable to indomethacin or acetylsalicyclic acid.
\end{abstract}

Keywords: Anti-inflammatory, analgesia, antipyrexia, betulinic acid, Tetracera potatoria

\section{Introduction}

Inflammation is the local response of living tissues to injury. It is the defensive reaction of the body to eliminate or limit the spread of injurious agent. Oedema formation, leukocyte infiltration and granuloma formation are some components of inflammation observed as responses to tissue injury (Mitchell and Cotran, 2000; Li et al., 2009). However, uncontrolled inflammation in the body has resulted in several disease conditions which include cardiovascular diseases, auto-immune diseases (such as Lupus erythematosus, rheumatoid arthritis), asthma and cancers (Coussens and Werb, 2002; Rakoff-Nahoum, 2006). Many anti-inflammatory agents from natural sources which were derived from plant, animal and microbial sources, as well as synthetic and semi-synthesis formulations of these agents, have been used in medical care of these diseases.

Plants in particular continue to serve as major resources of drugs generally for therapeutic purposes and many of the currently available drugs have been derived directly or indirectly from plants. Alongside these plants which have been fully explored for their medicinal potentials, there are many un-investigated or under-investigated plants which have remarkable medicinal effects.

Tetracera potatoria (family Dilleniaceae) is a scandent shrub or climber up to $5 \mathrm{~m}$ long. The stem holds a clear watery sap, which could be obtained by cutting (Oluwole et al., 2008). The plant is widespread from Sudan and Congo Republics into West Africa. T. potatoria is used extensively in ethnomedicinal practice in West Africa for treatment of diseases of inflammatory origin. The sap and the powdered leaf are used for treatment of toothache and cough, and it is also administered to lactating mothers as a galactogogue (Adesanwo et al., 2003). The aqueous extract of the root is used as a remedy for intestinal disorders, while the stems are macerated in its own sap and administered for treatment of leprosy and stomach complaint in Senegal (Burkill, 1985).

Adesanwo et al. (2003) reported that Tetracera potatoria and its constituent betulinic acid reduced gastric acid secretion and increased rate of healing of experimentally-induced gastric ulceration. This research is a further study on the pharmacological activity of betulinic acid, a bioactive principle isolated from $T$. potatoria. The anti-inflammatory and analgesic effect of this bioactive compound will be assessed in this study.

\section{Materials and Methods \\ Fractionation of Tetracera potatoria \\ Solvent-solvent partitioning of $T$. potatoria}

Fresh leaves of Tetracera potatoria were harvested in April, 2008 at Obafemi Awolowo University, and it was authenticated at the Herbarium of the Department of Botany by Mr. Ademoriyo. A voucher specimen was deposited with number IUH 16425 . The leaves were air dried at room temperature and pulverised with a mortar and pestle. $1.3 \mathrm{~kg}$ of the powdered Tetracera potatoria was soaked in N-hexane for 72 hours after which it was filtered and the remaining residue was air dried overnight. Soaking in solvent and drying of the residual plant material were subsequently repeated using ethyl acetate and methanol respectively as the solvent. The extracts obtained were clarified by filtration through celite on water pump and were then concentrated in vacuo using a rotary evaporator (Rotavapor R-210, Switzerland) at low temperatures. The remaining moisture was finally removed by freeze-drying. The extract obtained from n-hexane was designated NHTPF and it weighed $35 \mathrm{~g}$. The extract from ethyl acetate and methanol were designated EATPF (17.5g) and MTPF (85g) respectively. 


\section{Isolation of Betulinic acid}

EATPF was pre-absorbed on silica gel and fractionated on Accelerated gradient chromatography (AGC), a medium pressure liquid chromatography using a gradient elution with hexane/ethyl acetate mixtures. Sub-fractions obtained were monitored with analytical Thin Layer Chromatography (TLC) and similar sub-fractions were pooled. The solid obtained from the pooled sub-fractions which eluted with $40 \%$ ethyl acetate / $60 \%$ hexane solvent combination was further purified by use of vacuum liquid chromatography. After drying of the purified sub-fraction, it yielded a colourless crystalline solid compound. The structure of the compound was elucidated by Nuclear Magnetic Resonance (NMR) and Infra-red (IR) spectroscopy, including attached proton test spectrum of its acetylated product and comparison with authentic samples was done. The NMR data is in agreement with those reported by earlier workers (Andrenick et al, 1995; Adesanwo et al., 2003).

\section{Experimental animals}

Fifty adult male Swiss mice (18-20 g) and 50 adult Wistar rats (150-180g) of both sexes obtained from the Animal House of Department of Animal Sciences, Obafemi Awolowo University, Ile-Ife, Nigeria were used. The animals were maintained under standard environmental conditions of 12 hour light/dark and had free access to standard diet and water ad libitum. These animals were randomly divided into groups of five animals each. Three treatment groups were administered with betulinic acid at a dose of $10,20 \mathrm{or} 40 \mathrm{mg} / \mathrm{kg}$ b.w and one group was administered with indomethacin $(10 \mathrm{mg} / \mathrm{kg})$ or acetyl salicylic acid $(150 \mathrm{mg} / \mathrm{kg})$ as standard anti-inflammatory or analgesic agent respectively. A fifth group served as the control and was administered with distilled water $(10 \mathrm{ml} / \mathrm{kg})$. The animal ethical committee of the Faculty of Agriculture, Obafemi Awolowo University, Ile-Ife approved the protocols for the study.

\section{Carrageenan-induced paw oedema in rats}

Pedal oedema was induced according to the method described by Okoli et al. (2007). Following an overnight fast, betulinic acid (10, 20 or $40 \mathrm{mg} / \mathrm{kg}$ ) was administered intraperitoneally to rats in three groups. One group was administered with indomethacin $(10 \mathrm{mg} / \mathrm{kg})$, while a fifth group was administered with distilled water only $(10 \mathrm{ml} / \mathrm{kg})$. One hour after treatment, $0.2 \mathrm{ml}(2 \% \mathrm{w} / \mathrm{v})$ of carrageenan was injected into the subplantar region of the right hind paw. The paw size was measured before injection $(0 \mathrm{hr})$ and at intervals of $1,2,3,4$ and 5 hours post-carrageenan injection by using the cotton thread method (Hess and Milonig, 1972; Olajide et al., 2000). Cotton thread was wrapped around the paw and the circumference was measured with a metre rule. The inhibition of formation of paw oedema was calculated according to the following formula:

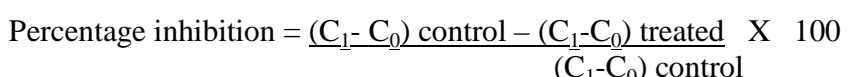

where $\mathrm{C}_{1}$ is paw size after albumen injection, $\mathrm{C}_{0}$ is paw size before albumen injection.

\section{Carragenaan-induced pulmonary oedema in mice}

Five groups of mice were pre-treated as earlier mentioned prior to the induction of pulmonary oedema. After 1 hour, carrageenan $(0.25$ $\mathrm{ml}, 0.75 \% \mathrm{w} / \mathrm{v}$ in saline) was injected intraperitoneally to each of these rats. Four hours later, the animals were sacrificed by cervical dislocation. The lungs of the mice were harvested and weighed. The weight of lungs from rats pre-treated with BA or indomethacin was compared to those of control group mice. The inhibition of formation of oedema was calculated according to this formula: $(1-\mathrm{T} / \mathrm{C}) \mathrm{X} 100$

where: $\mathrm{T}$ - Treated rat

C - Control rat.

\section{Acetic acid-induced abdominal writhing response in mice}

The method used was as described by Adzu and Haruna (2007). Mice in the test group received betulinic acid at the doses of 10, 20 and $40 \mathrm{mg} / \mathrm{kg}$ b.w intraperitoneally and indomethacin at $10 \mathrm{mg} / \mathrm{kg}$ orally. The control animals received distilled water ( $2 \mathrm{ml})$. One hour after, $0.2 \mathrm{ml}$ of $0.6 \%$ acetic acid was intraperitoneally injected to each mouse. The number of abdominal writhes (constrictions) that occurred between 5 - 25 minutes post administration of acetic acid was counted and recorded.

\section{Zymosan-induced fever in rats}

The groups of rats used for this study were pre-treated as earlier explained and one hour after, the rectal temperature of all the rats was taken using a rectal thermometer. Thereafter, zymosan at the dose of $0.5 \mathrm{mg} / \mathrm{kg}$ was injected intraperitoneally. The rectal temperature was subsequently monitored every hour, up to 4 hours post zymosan injection.

\section{Results \\ Anti-inflammatory study \\ Carrageenan-induced paw oedema}

A dose dependent inhibition of formation of oedema was observed in rats administered with betulinic acid (BA). At 180 minutes postinjection of carrageenan, the change in paw sizes of the rats administered with BA at a dose of $20 \mathrm{and} 40 \mathrm{mg} / \mathrm{kg}$ b.w was significantly lower ( 0.38 and $0.24 \mathrm{~cm})$ than that observed in the control rats $(0.70 \mathrm{~cm})$, and the change in paw size of rats administered with the highest dose of BA was comparable to indomethacin $(0.20 \mathrm{~cm})$ (Table 1$)$. 
http://dx.doi.org/10.4314/ajtcam.v11i1.5

Carrageenan-induced pulmonary oedema

The mean weight of the lungs of mice administered with BA $(0.84 \pm 0.06 \mathrm{~g}, 0.80 \pm 0.03 \mathrm{~g}$ and $0.62 \pm 0.04 \mathrm{~g})$ was dose-dependently reduced compared to those of control group mice. The mean weight of lungs of rats administered with the highest dose of BA (400mg/kg b.w) was nonsignificantly ( $>0.05)$ higher than those of mice administered with indomethacin $(0.55 \pm 0.05 \mathrm{~g})$ and acetylsalicylic acid $(0.58 \pm 0.06 \mathrm{~g})($ Table 2$)$.

Table 1: The effect of betulinic acid on inflammation induced by injection of carrageenan into rat paw

\begin{tabular}{lllll}
\hline Treatment & $\mathbf{0}$ minute $(\mathbf{c m})$ & $\mathbf{1 8 0}$ minutes $(\mathbf{c m})$ & $\begin{array}{l}\text { Change in paw size } \\
(\mathbf{c m})\end{array}$ & Inhibition (\%) \\
\hline BA (10mg/kg) & 2.38 & $3.00^{\mathrm{b}}$ & $0.62^{\mathrm{b}}$ & $11.0^{\mathrm{b}}$ \\
BA (20 $\mathbf{m g} / \mathbf{k g})$ & 2.38 & $2.76^{\mathrm{b}}$ & $0.38^{\mathrm{b}}$ & $45.7^{\mathrm{b}}$ \\
BA (40mg/kg) & 2.36 & $2.60^{\mathrm{b}}$ & $0.24^{\mathrm{b}}$ & $68.6^{\mathrm{b}}$ \\
Acetylsalicylic acid (150mg/kg) & 2.30 & $2.50^{\mathrm{b}}$ & $0.20^{\mathrm{b}}$ & $71.4^{\mathrm{b}}$ \\
Control (Dist $\left.\mathbf{H}_{\mathbf{2}} \mathbf{0}\right)$ & 2.34 & $3.04^{\mathrm{a}}$ & $0.70^{\mathrm{a}}$ & $0.00^{\mathrm{a}}$ \\
\hline
\end{tabular}

Values with different superscript are statistically significant at $\mathrm{p}<0.05$

Table 2: Lung weight ( $\mathrm{g}$ ) and percentage inhibition of pulmonary oedema induced by intra-peritoneal injection of carrageenan to rats pre-treated with betulinic acid

\begin{tabular}{lll}
\hline Treatment & Weight of lung $(\mathbf{g})$ & Percentage inhibition (\%) \\
\hline BA (10mg/kg) & $0.84 \pm 0.06^{\mathrm{b}}$ & 25.66 \\
BA (20mg/kg) & $0.80 \pm 0.03^{\mathrm{cb}}$ & 29.20 \\
BA (40mg/kg) & $0.62 \pm 0.04^{\mathrm{cbd}}$ & 45.13 \\
Acetylsalicylic acid (150mg/kg) & $0.58 \pm 0.06^{\mathrm{cd}}$ & 48.67 \\
Indomethacin (10mg/kg) & $0.55 \pm 0.05^{\mathrm{d}}$ & 51.33 \\
Control (Dist $\left.\mathbf{H}_{\mathbf{2}} \mathbf{0}\right)$ & $1.13 \pm 0.20^{\mathrm{a}}$ & 0.00 \\
\hline
\end{tabular}

Values with different superscript are statistically significant at $\mathrm{p}<0.05$

\section{Analgesic study}

Acetic acid-induced writhing test

A dose-dependent reduction in the mean number of abdominal writhing movements was observed in mice administered with BA $(28.20 \pm 0.80,21.09 \pm 1.40$ and $17.20 \pm 0.80)$, and these were significantly lesser than that observed in control mice (34.40 \pm 1.30$)$. The mean abdominal writhing observed in mice administered with BA at a dose of $40 \mathrm{mg} / \mathrm{kg}$ b.w was comparable to that observed in mice administered with indomethacin (16.30 \pm 4.00$)$ (Table 3).

Table 3: The effect of betulinic acid on abdominal writhing movement in mice induced by injection of acetic acid

\begin{tabular}{ll}
\hline Treatment & No of writhing \\
\hline BA (10mg/kg) & $28.20 \pm 0.80^{\mathrm{b}}$ \\
BA (20mg/kg) & $21.09 \pm 1.40^{\mathrm{c}}$ \\
BA (40mg/kg) & $17.20 \pm 0.80^{\mathrm{c}}$ \\
Indomethacin (10mg/kg) & $16.30 \pm 4.00^{\mathrm{c}}$ \\
Control (Dist $\left.\mathbf{H}_{\mathbf{2}} \mathbf{0}\right)$ & $34.40 \pm 1.30^{\mathrm{a}}$ \\
\hline
\end{tabular}

Values with different superscript are statistically significant at $\mathrm{p}<0.05$

\section{Antipyretic study \\ Zymosan-induced fever}

The rise in temperature of rats administered with BA was less than $1.5^{\circ} \mathrm{C}$ after one hour post-induction of fever, with significantly lower temperatures in these rats compared with control group rats throughout the course of the experiment. A steady rise in the temperature of rats administered with BA at $10 \mathrm{mg} / \mathrm{kg}$ was observed with the maximum temperature rise of $1.00 \pm 0.25^{\circ} \mathrm{C}$ in these rats observed at 3 hours postinduction of fever. For rats administered with BA at a dose of $40 \mathrm{mg} / \mathrm{kg}$, a sharp decline from $0.95 \pm 0.05^{\circ} \mathrm{C}$ to $0.00 \pm 0.00^{\circ} \mathrm{C}$ occurred in the temperature between $2-3$ hours post-induction of fever. The temperature of these rats had returned to pre-induction values by 3 hours postinduction of fever and this compound was more effective in lowering the temperature than acetylsalicylic acid $\left(0.30 \pm 0.10^{\circ} \mathrm{C}\right)(\mathrm{Table} 4)$.

Table 4: The effect of betulinic acid on temperature $\left({ }^{\circ} \mathrm{C}\right)$ of rats injected with zymosan

\begin{tabular}{lllll}
\hline Treatment & $\mathbf{1 ~ h r}$ & $\mathbf{2} \mathbf{~ h r}$ & $\mathbf{3 ~ h r}$ & $\mathbf{4} \mathbf{~ h r}$ \\
\hline BA (10mg/kg) & $0.20 \pm 0.01^{\mathrm{c}}$ & $0.50 \pm 0.15^{\mathrm{b}}$ & $1.00 \pm 0.25^{\mathrm{b}}$ & $0.35 \pm 0.25^{\mathrm{b}}$ \\
$\mathbf{B A}(\mathbf{2 0} \mathbf{m g} / \mathbf{k g})$ & $1.30 \pm 0.70^{\mathrm{b}}$ & $1.40 \pm 0.80^{\mathrm{c}}$ & $1.60 \pm 0.90^{\mathrm{c}}$ & $1.40 \pm 0.4^{\mathrm{c}}$ \\
$\mathbf{B A}(\mathbf{4 0} \mathbf{m g} / \mathbf{k g})$ & $1.10 \pm 0.20^{\mathrm{b}}$ & $0.95 \pm 0.05^{\mathrm{b}}$ & $0.00 \pm 0.00^{\mathrm{b}}$ & $0.00 \pm 0.00^{\mathrm{b}}$ \\
Acetylsalicylic acid (150mg/kg) & $1.20 \pm 0.01^{\mathrm{b}}$ & $0.50 \pm 0.10^{\mathrm{b}}$ & $0.30 \pm 0.10^{\mathrm{b}}$ & $0.20 \pm 0.05^{\mathrm{b}}$ \\
Control (Dist $\left.\mathbf{H}_{\mathbf{2}} \mathbf{0}\right)$ & $1.95 \pm 0.80^{\mathrm{a}}$ & $2.20 \pm 1.00^{\mathrm{a}}$ & $2.10 \pm 0.10^{\mathrm{a}}$ & $1.85 \pm 0.05^{\mathrm{a}}$ \\
\hline
\end{tabular}

Values with different superscript are statistically significant at $\mathrm{p}<0.05$

\section{Discussion}

Findings from this study show that betulinic acid had potent anti-inflammatory and analgesic activities comparable to indomethacin or acetylsalicylic acid. The anti-inflammatory activity was demonstrated by the inhibition of formation of paw and pulmonary oedema in rats and 


\section{http://dx.doi.org/10.4314/ajtcam.v11i1.5}

mice. Oedema formation is the result of a synergism between various inflammatory mediators that increase vascular permeability and/or the mediators that increase blood flow (Ialenti et al., 1995). Increased vascular permeability is a major feature of acute inflammation (Vane and Botting, 1995) and this increased permeability results from contraction and separation of endothelial cells at their boundaries, exposing the basement membrane which is freely permeable to plasma proteins and fluid.

The models of inflammation used to study the anti-inflammatory activity of betulinic acid are widely used for determining the acute phase of inflammation (García et al., 2004) which usually presents as two phases: early and late phase. In the early phase, the release of mediators of acute inflammation such as histamine, serotonin and bradykinin occur, while prostaglandins are released in the late phase of inflammation (Salvemini et al., 1996; Zeashana et al., 2009). The anti-inflammatory activity of this compound was more profound after 2 hours post-injection of the phlogistic agent. This suggests that the mechanism of anti-inflammation is mediated more via inhibition of prostaglandin synthesis and/or release.

Betulinic acid also demonstrated potent analgesic activity as shown by inhibition of pain sensation in the mice. Response to pain, observed as abdominal writhing movement, was significantly reduced indicating that betulinic acid possesses potent analgesic activity. The exact mechanism of analgesic activity of betulinic acid cannot be ascertained in this study because the model of analgesic used is only a strong indicator of the presence of analgesic activity in a compound. Acetic acid-induced abdominal writhing is mediated by stimulation of peritoneal mast cells (Ribeiro et al., 1991), acid sensing ion channel and the prostaglandin pathways (Di Rosa et al., 1971) which are non-specific indicators of centrally or peripherally mediated analgesia.

Betulinic acid also prevented rise in body temperature induced by the injection of Zymosan. Rise in body temperature is a response to endogenous or exogenous pyrogens which stimulates the chemotactic trigger zone of the brain responsible for temperature regulation in the body. Zymosan acts as an exogenous pyrogen and causes fever by the induction of cytokines and prostaglandins. Antipyretics are known to prevent rise in body temperature generally in response to endogenous pyrogens as excessive rise in body temperature may cause irreversible tissue damage and possibly death (Tijani et al., 2008). In the cascade of events leading up to induction of fever, pyrogens activate cyclooxygenase (COX) which is the enzyme that converts arachidonic acid to prostaglandin (PG). The dose dependent inhibition of the rise in body temperature by betulinic acid may be related to its established ability to inhibit prostaglandin synthesis.

In this study, betulinic acid demonstrated potent anti-inflammatory, analgesic and antipyretic activities. Betulinic acid, a triterpene has been isolated from different plants across the world (Bringmann et al., 1997, Siddiqui et al., 1997). During the last two decades, triterpenes have attracted attention because of its pharmacological potentials with particular reference to its antioxidant activity (Jager et al., 2008; Lin et al., 2009; Schwarz et al., 2012). Betulinic acid was previously isolated from Triphyophyllum peltatum and Ancistrocladus heyneanus and its antimalarial effect was verified (Bringmann et al., 1997). Betulinic acid was first isolated from T. potatoria by Adesanwo et al. (2003). Adesanwo et al., (2003) described the anti-ulcerogenic and gastric protectant effects of betulinic acid. Lin et al. (2009) also explored free radical scavenging activity of betulin as a protectant of chondrocytes and its ability to maintain proliferation and basic activities of chondrocytes.

\section{References}

1. Adesanwo JK, Ekundayo O, Oluwole FS, Olajide OA, Van Den Berge AJJ, Findlay JA (2003). The effect of Tetracera potatoria and its constituent betulinic acid on gastric acid secretion and experimentally-induced gastric ulceration. Nig. J. Physiol. Sci., 18 (1): 1-2.

2. Adzu B, Haruna AK (2007). Studies on the use of Zizyphus spina-christi against pain in rats and mice. Afri. J. Biotech., 6 (11): 1317-1324.

3. Andrenick AD, Wright TR, Otto S (1995). Antibacterial triterpenoids from Dillenia papuana and their structure- activity relationships. Phytochem., 40 (6): 1691-1695.

4. Bringmann G, Saeb W, Assi LA, Francois G, Narayanan A, Peters K, Peters EM (1997). Betulinic acid: Isolation from Triphyophyllum peltatum and Ancistrocladus heyneanus, antimalarial activity, and crystal structure of the benzyl ester. Planta Med., 63: 255-257.

5. Burkill HM (1985). The useful plants of West Tropical Africa, Vol 1.

6. Coussens LM, Werb Z (2002). Inflammation and cancer. Nature, 420 (6917): 860 -867

7. Di Rosa M., Giround JP, Willoughby DA (1971). Studies of the acute inflammatory response induced in rats in different sites by carrageenan and turpentine. J. Pathol., 104: 15-29.

8. García M.D, Fernández MA, Alvarez A, Saenz MT (2004). Antinociceptive and anti-inflammatory effect of the aqueous extract from leaves of Pimenta racemosa var. ozua (Mirtaceae). J. Ethnopharmacol., 91: 69-73.

9. Ialenti A, Ianaro A, Moncada S, Di Rosa M (1995). Modulation of acute inflammation by endogenous nitric oxide. Eur. J. Pharmacol., 211:177-184

10. Jager S, Laszczyk MN, Scheffler A (2008). A preliminary pharmacokinetic study of botulin, the main pentacyclic triterpene from extract of outer bark of birch (Betulae alba cortex). Molecules, 13: 3224-3235.

11. Lin WY, Sadhasivam S, Lin FH (2009). The dose dependent effects of betulin on porcine chondrocytes. Proc Biochem., 44 (6): 678-684

12. Mitchell RN, Cotran RS (2000). In: Robinsons Basic Pathology, Seventh ed., New Delhi, Harcourt (India) Pvt., Ltd., Pp 33.

13. Okoli CO, Akah PA, Okoli AS (2007). Potentials of leaves of Aspilia africana (Compositae) in wound care: an experimental evaluation. BMC Compl Altern Med., 7: 24

14. Oluwole FS, Ayo JA, Omolaso BO, Emikpe BO, Adesanwo JK (2008). Methanolic extract of Tetracera potatoria, an antiulcer agent increases gastric mucus secretion and endogenous antioxidants Nig. J. Physiol. Sci., 23 (1-2): 79-83.

15. Rakoff-Nahoum S (2006). Why cancer and inflammation? Yale J. Biol. Med., 79 (3-4): 123-130

16. Ribeiro RA, Flores CA, Cunha FQ, Ferreira SH (1991). IL-8 causes in vivo neutrophil migration by a cell dependent mechanism. Immunol., $73: 472-471$.

17. Salvemini D, Wang ZQ, Bourdon DM, Stern MK, Currie MG, Manning PT (1996). Evidence of peroxynitrite involvement in the carrageenan-induced rat paw edema. Eur. J. Pharmacol., 303: 217-220

18. Schwarz S, Xavier NM, Csuk R, Rauter AP. (2012) Triterpene/Steroid glycoconjugates: Natural occurrence, synthesis and biological activities. Carbohydrate Chem., 37: 326-373

19. Siddiqui BS, Sabira-Begum F, Salimuzzaman S (1997). Isolation and structural elucidation of acylated pentacyclic triterpenoids from the leaves of Eucalyptus camaldulensis var. obtuse. Planta Med., 63 (1): 47-50.

20. Tijani AY, Uguru MO, Salawu OA (2008). Anti-pyretic, anti-inflammatory and anti-diarrhoeal properties of Faidherbia albida in rats. Afr. J. Biotech., 7 (6): 696-700.

21. Vane JR, Botting RM (1995). Inhibition of prostaglandin synthesis as a mechanism of action of aspirin -like drugs. Nature, 231: 232.

22. Zeashana H, Amresha G, Raoa CV, Singhb S (2009). Antinociceptive activity of Amaranthus spinosus in experimental animals. J. Ethnopharmacol., 122: 492496 